\title{
Whatever happened to compassionate Conservatism under the
}

\section{Coalition government?}

\author{
Hugh Bochel \\ School of Social and Political Sciences \\ University of Lincoln \\ Lincoln, LN6 7TS \\ hbochel@lincoln.ac.uk
}

\author{
Martin Powell \\ Health Services Management Centre \\ University of Birmingham \\ Birmingham, B15 2TT \\ m.powell@bham.ac.uk
}

\begin{abstract}
:
Following David Cameron's election as leader of the Conservative Party in late 2005, a series of initiatives suggested that he was seeking to reposition the Conservative Party, or perhaps to introduce some new thinking to the Party and to align it with interests and issues that it had not been linked with since at least the start of the Thatcher period. At the time, views among commentators varied about whether this was a genuine attempt to change the Conservative Party, including through a more compassionate approach to some social groups and problems, or whether it was simply designed to 'detoxify' the Party and to make it electable once more. However, many observers were unconvinced that the five years of the Coalition government saw significant evidence of the 'compassionate' ideas that Cameron and others sought to highlight prior to the 2010 general election. This article explores a number of possible reasons for the apparent disappearance of compassionate Conservatism in relation to social policies under the Coalition government. It suggests that rather than any one explanation, drawing upon a number of interpretations may provide the best understanding of the role and impact of compassionate Conservative ideas from 2010 to 2015.
\end{abstract}

Keywords: David Cameron; Conservative Party; compassionate Conservatism; progressive Conservatism; modern Conservatism; coalition government 
Following David Cameron's election as leader of the Conservative Party in December 2005, he and a number of other leading Conservatives sought to portray the Party as different, at least in some respects, from the ways in which it had been perceived under his immediate predecessors. Against wider arguments and positioning associated with Conservative modernisation (Garnett, 2010; Hayton, 2010; Bale, 2012; Griffiths, 2014; Kerr and Hayton, 2015), one area where that was particularly the case was in relation to social issues and policies (Bochel, 2011; Hayton and McEnhill, 2014; Page, 2014; Williams, 2015), so that on topics such as the NHS, inequality and social mobility, gender and family structure, Cameron and his allies argued that the Conservative Party recognised and would respond to the concerns of the public in a different manner. However, the nature and extent of any new approach have been questioned, along with the record of the Conservative-Liberal Democrat Coalition government in taking a more 'compassionate' approach in its social policies (for example, Beech and Lee, 2015; Bochel and Powell, 2016).

This article briefly traces the apparent re-emergence of compassionate Conservatism, before exploring seven possible explanations of what happened to it under the Coalition government of 2010-15. It suggests that while each of the first six has merits, a more complete understanding of the nature and role of different aspects of compassionate Conservatism as part of the wider modernisation project under Cameron can be gained by reflecting upon the variety of interpretations of it, the interests and audiences within and outside the Conservative Party that 'compassionate' ideas emerged from and were aimed at, and how they were reflected (or not) in policy. 


\section{The strange re-emergence of compassionate Conservatism}

Attempting to define compassionate Conservatism under David Cameron is problematic, not least because a range of other terms were also used, broadly interchangeably, by leading Conservatives, their critics, and commentators, including 'modern', 'progressive' and 'civic' Conservatism. For some, it also had resonance with arguments about compassionate conservatism in the United States (for example, Béland and Wadden, 2007; Olafsky, 2000). As the focus of this article is on the presentation by the Conservative Party of an apparently more 'compassionate' face on social issues, that is the umbrella term used here.

For three decades following the Second World War, the Conservatives were broadly seen as supporting the idea of the welfare state and generally 'progressive' approaches to poverty and social justice, although there were also recurring attempts to make social provision more efficient and to diminish the risks of dependency. Under Thatcher and Major the influence of the New Right meant that the welfare state was seen to have failed in many respects, including through creating a culture of dependency, and undermining the work ethic and a sense of personal responsibility, resulting in a greater emphasis on the market, and individuals and families themselves, in seeking to alleviate poverty. While some of these ideas fed into New Labour's approach from 1997-2010, for the Conservatives, elements of their policies and rhetoric under the Thatcher and Major governments 
made it difficult for them to counter accusations that they were an uncaring, or in the words of Theresa May, 'nasty' party (May, 2002).

After 1997, William Hague, lain Duncan Smith, and to a lesser extent Michael Howard, appeared to attempt to embrace more socially liberal and inclusive policies towards the start of their leaderships, but each soon moved back to the right (Bale, 2011; Bochel, 2011). The Party therefore fought the general elections of 2001 and 2005 largely on the basis of 'traditional' Conservative concerns, such as crime, immigration and Europe (Butler and Kavanagh, 2002; Kavanagh and Butler, 2005).

Following David Cameron's election as leader, a series of initiatives suggested that he was seeking to introduce new thinking to the Party, and to align it with interests and issues that it had not been linked with since at least the start of the Thatcher period (McAnulla, 2010; Page, 2010; Bochel, 2011; Griffiths, 2014; Kerr and Hayton, 2015). For example, in speeches Cameron appeared to make the case for a new approach, including to poverty (2006c) and anti-social behaviour (2006b), and highlighted a commitment to the NHS (2006a); he created six policy review groups, only one of which was directly concerned with econo mic matters, while one focused on social justice, chaired by lain Duncan Smith; and in January 2009 he launched the idea of 'progressive Conservatism' at the Demos think tank, talking about using Conservative means to achieve 'progressive ends', such as a fairer, more equal and safer society (for example, Robinson and Twyman, 2014). 
Of course, Cameron's approach was not new. David Willetts (1992) had pointed out that there were two strands to modern Conservatism - the commitment to the free market and the trust in community, and argued for the development of 'civic Conservatism' (Willetts, 1994; 2005a). He asserted that it was not sufficient for the Conservatives to be 'a bunch of backward looking people who want to recreate British society as it was in the 1950s' (Willetts, 2005b), and suggested that a 'new Conservatism' should combine a commitment to a strong economy with social justice (see also Willetts, 2005a). Notably, in 2002, following his 'epiphany' in Glasgow, Duncan Smith had set out a vision of 'compassionate Conservatism', aiming to reform public services and help 'the vulnerable' (Seldon and Snowdon, 2005). He established the Centre for Social Justice in 2004 , which was to play a significant role in providing the underpinnings for many of the Conservatives' arguments on poverty and social justice.

Although the bulk of the parliamentary Conservative Party at this period displayed largely 'Thatcherite' views (Bochel and Defty, 2007), there were a number who sought to argue for a different approach. In 2007, two MPs, Greg Clark and Jeremy Hunt, published a pamphlet, Who's Progressive Now?, in which they claimed that prog ressive values underpinned the Conservative Party under David Cameron. At the same time, other thinkers, such as Jesse Norman (for example, Norman and Ganesh, 2006; Norman, 2009), were also producing their visions of a compassionate Conservatism. 
This claim to a different approach to social issues reflected other developments under Cameron (Bale, 2011; Kerr and Hayton, 2015), such as a recognition of the challenge of environmental change, and the creation of an A-list for parliamentary candidates. Indeed, it can perhaps be seen as part of a much wider campaign, including to appeal to potential Liberal Democrat supporters (McGrath, 2009), while also helping provide a critique of what the Conservatives portrayed as Labour's 'failed' and 'statist' approach to tackling poverty and enhancing social mobility (as, for example, with Kruger, 2007).

Cameron and his fellow modernisers arguably pursued a twin track approach, attempting to distance themselves from their predecessors and to challenge the perception of the Conservatives as the 'nasty party', while still appealing to traditional Conservative supporters (see, for example, McAnulla, 2010; Buckler and Dolowitz, 2012; Griffiths, 2014), so that while talking about tackling poverty, supporting the NHS and climate change, they were also promoting long-standing Conservative views on subjects such as crime, family structures and personal freedom, and taking responsibility away from the state and giving it to individuals, families and communities. Even before dropping the commitment to match Labour's public expenditure plans, they saw limited government and lower taxes as part of the solution. They argued, therefore, that such an approach would involve 'a dramatic decentralisation, a big shift in emphasis... from the state to society' (Cameron, 2006c), and emphasised the role of the voluntary sector, including in tackling poverty. 


\section{Whatever happened to compassionate Conservatism?}

A number of commentators have suggested that the approach of the Conservatives, and indeed the Coalition government as a whole, was not particularly 'compassionate' (for example, Griffiths, 2012; Wright, 2012; Eaton, 2014; Patrick, 2015; Bochel and Powell, 2016), and that, similarly, the wider 'modernisation' project can be seen as a failure (Dommett, 2015; Kerr and Hayton, 2015). The remainder of this article explores what happened to compassionate Conservatism during that period. While there is a significant body of work on the Conservatives and the Coalition government, providing a variety of valuable insights, including into the ideological underpinnings and internal politics of the Conservative Party and the government, not all of it relates directly to the themes considered here, with, for example, the theme of 'compassion' frequently being overlooked. Drawing upon much of that work, and focusing primarily on the development of government policy, rather than ideology, this article identifies six initial possible explanations, and suggests that a seventh, considering them together, may assist in understanding the fate of 'compassionate' Conservatism under the Coalition:

1. It was primarily an electoral tool. This could be seen as consisting of two separate but related elements: an intention to 'detoxify' the Conservative brand; and an attempt to attract (the 'median') voters;

2. Compassionate Conservative ideas were largely restricted to a relative small (perhaps elite) group, primarily located within the parliamentary Party; 
3. Ideas that came under the broad banner of 'compassionate' Conservatism originated from more than one group within the Party, and these had in many respects quite different foci and views;

4. Compassionate Conservative ideas were largely overwhelmed and pushed off the policy agenda by 'events', most notably the financial crisis and its ramifications;

5. The ideas underpinning compassionate Conservatism reflected particular interpretations of 'compassion';

6. To some extent, like redistribution under New Labour, compassionate Conservatism was there, but it was not much talked about;

7. Finally, compassionate Conservatism might best be understood by reflecting upon more than one of these.

Clearly, the internal politics of the Coalition had an impact on the government's policies, and those dynamics have been reflected in consideration of Conservative statecraft (for example, Hayton, 2014; Gamble, 2015; Heppell and Seawright, 2015). However, for the most part it would be hard to argue that compassionate Conservative ideas on social policy were held back by Liberal Democrat resistance, and this is broadly reflected in the literature (for example, Beech and Lee, 2015; 
Seldon and Finn, 2015; Bochel and Powell, 2016). While interesting, the internal politics of the Coalition and their impact upon policy are not, therefore, discussed here, unless of direct relevance to the shape of policy.

As noted above, 'compassionate Conservatism' is used here as an umbrella term to cover those positions, that implied, explicitly or implicitly, a somewhat different approach on a variety of social issues from that which was underpinned primarily by a neo-liberal approach to economic and social policy, and indeed from Thatcherism. Obviously, each of these terms is problematic. For example, Robinson and Twyman (2014) note that 'progressive' has something of an ideological meaning, being associated in the UK with ideas of social justice, and state intervention. However, it also has a temporal meaning, and the two do not necessarily go hand-in-hand. Indeed, they note suggestions that ideas of 'progressive' politics may have originated with economic liberalism, rather than social liberalism, and that Margaret Thatcher also sought to use the language of progress. Similar points could be made with reference to the other words and phrases used in these debates. In addition, while a more precise definition might in some respects be advantageous for analytical purposes, leading Conservatives, their opponents, and indeed other commentators, tended to use the variety of terms largely interchangeably, albeit sometimes with particular emphases, or used different terms to describe the same thing. This article argues, therefore, that an understanding of compassionate Conservatism under the Coalition requires a recognition that it, and many related ideas, were, at times, either by accident or design, vague and amorphous. 


\section{Compassionate conservatism was primarily an electoral tool}

As Buckler and Dolowitz (2012) highlight, political parties constantly adapt their policies and rhetoric as a normal part of democratic competition, and while this generally results in relatively small shifts, at times this may be more radical. Unsurprisingly, given the long period in Opposition, some have argued that Cameron's emphasis on compassionate Conservatism was largely, although not necessarily entirely, designed to help make the Conservatives electable again, not least by seeking to portray the Party as having moved on from the Thatcher era.

Griffiths (2014), for example, highlights the context against which Cameron became Conservative leader. In late 2005 the Conservatives had suffered a third successive election defeat, had become 'contaminated' as the 'nasty party', were associated with scandal and were divided over Europe. Francis Maude (2005) argued within the Party that 'change is self-evidently needed', noting the loss of support among women, younger people and the large conurbations outside London. In the leadership contest Cameron was widely seen as a 'moderniser', who would reform the Party, in contrast to his opponent, David Davis, who was seen as more in line with Thatcherite ideas. Having become leader, Cameron sought to change the Party's image, including over the environment, some social issues, and the NHS. As the Conservatives took the lead over Labour in opinion polls, some, understandably, came to see Cameron as dragging the Party back to the centre and to electoral success. However, Griffiths concludes that 'Cameron's account of progressive conservatism was part of a change of image, not substantively of policy or ideology: as such, it is firmly on the right of British politics' (p. 38). 
On similar lines, Bale (2012) argues that while, as leader of the opposition, Cameron appeared to have 'endlessly avowed enthusiasm for the centre ground', supported the NHS and claimed to value public sector workers, 'if one scratches beneath the surface appearance of centrism that he initially believed was vital to securing electoral victory, Cameron was and is ultimately no less of a Thatcherite than the vast majority of his colleagues' (p. 89), and suggests that this was demonstrated even before May 2010 when 'he reverted to orthodox type in response to the domestic consequences of the global economic crisis' (p. 89). Hayton (2014), too, asserts that Cameron's distancing of the Conservatives from Thatcherism was 'more symbolic than substantial' (p. 8), and that the Conservatives' modernisation strategy was largely an attempt at detoxification, including 'by association with language... not traditionally linked to the party' (p. 9) (see also, Hayton, 2015).

Page (2015a), too, suggests that when Cameron became leader he and his closest associates felt that 'the construction of a new, softer, social narrative was necessary to 'detoxify' the Conservatives and to highlight how the Party's agenda in this sphere differed from the overly statist strategy of New Labour' (p. 130). For Page (2014), the prog ressive elements of Cameron's conservatism includied: a more relaxed approach to diverse lifestyles; a toning down of the anti-state rhetoric associated with neoliberal approaches; and a recognition that the state could play some role in protecting people from poverty and disadvantage (for example, Letwin, 2002; Willetts, 2002). He suggests that in the attempts to dispel the idea that the Conservatives were uncaring, great importance was paid to the role of voluntarism 
and civic institutions in creating the 'Big Society', initially appearing to draw on ideas such as those of Blond (2010), together with conditional state support for those who were unable to provide for themselves. McAnulla (2010), too, notes that one of the effects of Cameron's anti-statism was to make the Conservatives' approach to issues such as social justice and decentralisation distinguishable from New Labour's approach, while it may also have contributed to making traditional Conservative ambitions palatable to the post-Blair electorate.

Heppell (2013) argues that, following the failure of the core vote strategy at the 2001 and 2005 general elections, Cameron's supporters believed that a repositioning of the Party was necessary. For some, this modernisation involved symbolic changes, attempting to pull the Party away from Thatcherism, and moving on to new policy ground. In that sense, he suggests that Cameron was replicating Blair's strategy.

From these perspectives, therefore, two related but separate aims can be identified from the strategy of highlighting compassionate Conservatism. Firstly, there was the attempt to detoxify the Conservative Party, as reflected, for example, in Cameron's statement, following his election as Conservative leader, that 'there is such as thing as society', which deliberately contrasted with Thatcher's claim (albeit often taken out of its full context), that 'there is no such thing as society'. Secondly, there was an attempt to counter New Labour's position by bringing the Conservative Party towards the political centre on issues such as the NHS and social divisions, while also making clear a difference between the parties on the role and responsibilities of the state, and of individuals, communities and society. Hodkinson and Robbins (2012) 
argue that in their 2010 general election manifesto the Conservatives sugar-coated 'their agenda for "public spending control" with the compassionate one-nation rhetoric of "we are all in this together"' (p. 64), while McAnulla (2010) suggests that prior to the 2010 general election Cameron had not only 'moved the Conservatives onto the broad territory staked out in New Labour's third way' (p. 311), but also contended that they were best placed to defend third way themes. Even following the election, his move to establish a coalition with the Liberal Democrats appeared to strengthen his claim to be interested in governing in ways that transcended traditional dividing lines.

One other thing that may have helped sway interpretations of the Conservative Party in Opposition was the involvement of newer think tanks, such as the Centre for Social Justice, Policy Exchange and ResPublica, in addition to longer established groups, such as the Institute of Economic Affairs and the Adam Smi th Institute. Pautz (2013) suggests that this was a way of reaching new audiences and bringing new ideas into the Party, provided ideological support for the modernisers and recruiting grounds for personnel, and allowed the development of policy outside the party machinery. However, their influence remained uncertain, and, other than the Centre for Social Justice, they were far from the only or even the major shapers of ideas, let alone policy.

The combination of symbols and substance, and the different arguments and assertions made by the advocates of a new direction, as well as the unwillingness to produce precise promises and commitments that might allow the development of 
critiques and alienate potential allies, meant that, as Bale (2013) notes, Conservative modernisation 'was always heavier on diagnosis than on prescription' (p. 135), and made the extent of change hard to assess. The lack of precision also meant that it could recognise that society and social mores had changed, and the Party could therefore be urged to end its war on single parents; but, at the same time, could see society as 'broken', with many of its problems being rooted in family breakdown and poor parenting, so that there was the clear impression that such hostilities had not in fact ended. He also highlights the ambiguities of Conservative modernisation around public services and public expenditure. Until the financial crisis there appeared to be a view among Conservative modernisers that promises of tax cuts and consequent restrictions on public spending had failed to persuade voters that the Conservatives could be trusted to run public services in the way that many of them wanted them run. However, the financial crisis allowed the Conservatives to drop their commitment to matching Labour's spending plans and return to an agenda of spending cuts. Bale (2013) therefore argues that Conservative modernisation was not simply a shallow attempt to gain votes, but neither was it a noble cause that was betrayed by cynics or blown off course by events; rather its lack of development was a result of its original ambivalence and contradictions, which were always likely to be more exposed when the Party was in office. Indeed, he notes that some elements of the socially liberal agenda, such as same sex marriage and ring-fencing overseas aid spending, were pursued, sometimes at a cost to the reputations of their advocates, including the Prime Minister himself. 
Even once in government, compassionate Conservatism might be seen as having played a valuable role for the Conservatives, not least in terms of the rhetoric helping restrict the efficacy of some of the arguments of the Labour Party, and indeed their Liberal Democrat Coalition partners, and in the attempts of the Chancellor, George Osborne, in particular, to use 'welfare' to highlight differences with Labour.

2. Compassionate Conservative ideas were largely restricted to a relatively small group, primarily located within the parliamentary Party

Others have argued that the Cameronite tendency was a relatively small and elite group (Rawnsley, 2009; Kirkup, 2012), with the Conservative MP, Nadine Dorries, describing Cameron and Osborne as 'two arrogant posh boys' (BBC, 20121), and in many ways this reflects other interpretations of the development of the modernising tendency within the Conservative Party. Indeed, Bale (2012) argued that the gap between the Conservatives and the Liberal Democrats in the Coalition government was larger than some on the Conservative side had hoped, because the number of Conservatives willing and able to reach across the divide was so small. While sceptical about the motives for and extent of Conservative modernisation, Hayton (2014) notes that for some 'modernisers', working with the Liberal Democrats appeared to provide the possibility of completing the transformation of their party. However, the degree of resistance to change within the Party is also noted by Page, who, reflecting on Peter Lilley's attempt in 1999 to persuade the Conservatives to adopt a more compassionate approach, notes that it 'only served to harden the 
resolve of those neo-liberal Conservatives who believed that any concerted attempt to distance the party from the Thatcher legacy would be counter-productive as well as treacherous' (2015a, p. 121), and that the furore over the speech persuaded the then leader, Hague, not to pursue a more progressive approach on social issues.

Indeed, until and even under Cameron's leadership, support for a more socially inclusive approach to lifestyle choices, let alone a 'softer' approach to social policies more generally, was limited, with, for example, the parliamentary Party opposing the Labour government's repeal in 2003 of Section 28 of the Local Government Act 1988. Even under the Coalition, attempts to take a more liberal line saw considerable opposition, with 130 Conservative MPs rebelling over the introduction of same sex marriage in 2013.

Heppell's (2013) findings, drawing on division lists and early day motions, and on public comments by MPs, reinforce the view that Cameron and the modernisers were in a significant minority, with less than one-third of the Parliamentary Conservative Party endorsing social liberal positions, and fewer than one-quarter of Conservative ministers being social liberals, although he also suggested that the 2010 cohort of MPs were more likely to hold such views.

Interviews on the attitudes to welfare of MPs during 2004-5 (Bochel and Defty, 2007) found that a mong Conservative MPs, while, compared with the 1980s (Bochel, 1992), there was still considerable support for a minimalist approach to state provisions, there was more support for a more active role for the state in improving 
people's lives, and for government in building communities and improving life chances. MPs from the latter group stressed the need to combat poverty, particularly among children and older people. However, there were limits to the support for a role for the state, with, for example, none of those interviewed feeling that general taxation should be increased to pay for welfare provision. Similarly, fewer than one in ten Conservative MPs felt that the benefits system was effective in getting money to people who needed it. While some of these views appeared to be in part a reaction to and recognition of New Labour's policy dominance at the time, there was a small group who clearly felt that the Conservative Party had been making the wrong arguments, and that it should seek to distance itself from the policies and rhetoric of the Thatcher and Major governments. However, they appeared to be largely isolated individuals (several, indeed, said that they did not talk to their colleagues about these topics), rather than a coherent grouping. Nevertheless, around the time of David Cameron's election as leader, a number of them did emerge among the modernisers. In contrast, interviews with sixteen Conservative MPs from the 2010 intake found their attitudes on social policy issues closer to those of Conservative MPs from the 1980s, with, for example, a reemergence of ideas about those who are 'deserving' and 'undeserving' of state support, and the need to target support towards the 'genuinely disabled', and with half identifying the risks of dependency as a major challenge (Bochel and Defty, 2014), a rather different picture from that described by Heppell (2013), as noted above, although perhaps reflecting different policy areas. Conservative peers, perhaps unsurprisingly, tended to have views that had more in common with the policies of the Conservative Party in the Thatcher period than with the 
compassionate or modernising tendency in the House of Commons (Bochel and Defty, 2010).

This lack of enthusiasm for some compassionate Conservative ideas was also apparent in the Party outside Parliament. A survey of Conservative Party members in 2013 found, for example, that they placed themselves on average at 8.4 on a leftright scale, with 0 as very left wing and 10 as very right wing, compared with David Cameron, who they placed at 7.0, and Conservative MPs, who they placed at 7.9 (Bale and Webb, 2013). UKIP was placed at 9.1. While Bale and Webb found that views on issues varied, they described social conservatism as 'pervasive' (p. 5), although, equally, there was no desire to see cuts in spending on the NHS. However, Webb and Childs (2011) suggested that among two of the three ideological tendencies that they identified within the Conservative Party, Liberal and Traditional Conservatives (the third being Thatcherite Conservatives), there was some sympathy for progressive views on social issues, and that depending on the issues that he was seeking to address, Cameron might be able to put together different coalitions of support from among the three groups.

It is also possible to argue that the views of both Conservative MPs and members aligned with those of the public in some respects, but differed in others, with a number of studies having suggested that public attitudes towards the poor, and particularly the unemployed have hardened in recent years (for example, TaylorGooby, 2013; Baumberg, 2014), while there remains a strong commitment to state provision in a wide range of areas (Defty, 2016). 
3. The ideas that came under the broad banner of compassionate Conservatism originated from different groupings within the Party, and in many respects these had quite different foci and views

Potentially covering some of the same ground as 5, below, this argument can be made from two perspectives. Firstly, as noted above, a variety of different terms were used to describe perceived changes of emphasis in the Conservative Party, and the broad and interchangeable use of these, by both politicians and commentators (see also Dommett, 2015; Kerr and Hayton, 2015), was likely to lead to the conflation of different ideas and perspectives. Secondly, there may have been very real differences between the proponents of these approaches, even if they were frequently using the same words and even focusing on the same social problems and groups.

The tendencies reflected in the development of compassionate Conservative ideas draw upon very different philosophical and ideological backgrounds and different political imperatives, including, potentially, the 'borrowing' of ideas associated with elements of the Republican Party in the United States around the late 1990s and early 2000s (although Norman and Ganesh [2006], for example, specifically distance their ideas from the 'compassionate conservatism' of George W. Bush). This poses a number of potential questions, not least around exactly what was being talked about. For example, while some of the ideas of Willetts, Duncan Smith and Cameron might all have been seen as showing some degree of compassion, and to have varied 
somewhat from a 'true' Thatcherite agenda, they were frequently applied to different issues and elements of society, and it is far from clear to what extent Cameron's ideas were the same as Willetts' or Duncan Smith's, let alone Blond's 'Red Toryism'.

Griffiths (2014) differentiates Cameron's progressive conservatism from One Nation conservatism and Red Toryism, arguing that from Disraeli to the 1980s, One Nation conservatism involved progressivism as social justice, and used the state to achieve its ends, rather than cutting back the state. He suggests that the 'Red Toryism' of Blond (for example, 2010) and his think tank, ResPublica, on the face of it appeared closer to the Cameron position in its view that Britain is 'broken' and with some emphasis on local and community responses. However, while Cameron did appear at the launch of ResPublica, he stayed only briefly, and it is not clear that Blond's influence was ever more than ephemeral. Griffiths points out that Blond's proposed responses, including recapitalising the poor, never made it into Conservative policy, and were a long way from the policies pursued by the Coalition government, although the idea of the greater use of mutuals to provide public services did appear to survive until the early years of the Coalition. Blond's Red Toryism may therefore be seen as different, in blaming economic liberalism, as well as the state, for undermining structures such as church, family and civil society organisations, from other Conservatives who do not accept that there is a contradiction between neoliberalism and a good society (for example, Willetts, 2005b; Letwin, 2003; Osborne, 2009). 
Wiggan notes that, unlike Red Toryism, the 'self-defined progressive conservatism' (2011, p. 38) of leading Conservative politicians was useful precisely because it did not necessitate a break with neoliberalism. Rather, it allowed the Conservatives (and indeed the Coalition government) to 'voice concerns about poverty and social justice, while pursuing welfare reforms based on traditional Tory commitments to self-reliance, independence and the market' (p. 38). A similar argument might be made about the work of Norman (Norman and Ganesh, 2006; Norman, 2009), which provided intellectual support for some of Cameron's rhetoric and even policy development, including by highlighting a need for decentralisation, voluntarism and public service, while at the same time criticising some of the policies of previous Labour and Conservative governments. It is unsurprising therefore, that Bale (2013) points out that Conservative 'modernisation' could be interpreted very differently, with, for example, the socially liberal acceptance of single parents standing against 'broken' society and 'problem' families, and some aspects of multiculturalism against the reiteration that Britain is a Christian country.

Two of the main exponents of compassionate Conservatism were Cameron and Duncan Smith. While interpretations of Cameron's beliefs differ, Buckler and Dolowitz (2012) suggest that he consistently emphasised two principles: trust in people to act for themselves; and a shared responsibility to maintain the social fabric; although they note that these can be subject to a variety of ideological interpretations. Cameron was arguably generally both consistent and progressive in relation to elements of social liberalism, particularly around sexual orientation and lifestyles, where he took a more tolerant line than many of his predecessors. In his 
early days as leader he also criticised the Labour government for its failure to tackle poverty and inequality. Page (2011) suggests that Cameron sought to portray his party as modern and progressive, seeking 'to create a cohesive and tolerant society in which individuals would take greater responsibility for their own well being, philanthropy would flourish, civic society would be reinvigorated and poverty and inequality would become less well entrenched' (p. 35; see also Hickson, 2008; Garnett, 2010). Given the divisions within the Conservative Party, it is perhaps unsurprising that Beech (2015) notes that on social issues Cameron and some of his fellow modernisers felt much more comfortable with the Orange Book Liberal Democrats than with many of their own parliamentary colleagues, and that while the election in 2005 of Cameron as leader may have been a triumph for the social liberals within the Party, 'social conservatism is still a key philosophical position for a majority of Conservative $\mathrm{MPs}^{\prime}$ (p. 7). Indeed, in government, particularly around employment and social security, it was arguably the ideas of Duncan Smith, together with pressure for public expenditure cuts, that drove the Conservatives' agenda, with the work of the Centre for Social Justice on the 'broken society' having been influential. And, for Duncan Smith, as discussed below, compassionate Conservatism in many respects appears to draw upon very traditional Conservative views, including around individual responsibility and the idea of the family, while his 'compassion' reflects an intolerance of 'dependency'.

It is also possible to see elements of compassionate and prog ressive Conservatism as being concerned with redefining the relationship between citizens and the state, including more volunteering and greater use of philanthropy. Hodkinson and 
Robbins (2012) suggest that rather than simply being the antithesis of 'big government', the Big Society was an attempt 'to redefine the relationship between citizens and the state' (p. 64) through reforming the public sector and the role of the state, promoting community empowerment and encouraging philanthropy. Such a perspective arguably fits with Cameron's Big Society rhetoric, particularly around the 2010 general election, where he argued that the state 'must help families, individuals, charities and communities come together to solve problems' (Cameron 2009). Wiggan (2011) argues that civic Conservatives advocate less state intervention, preferring a strengthening of the social bonds of society, so that people may be more likely to rely on 'themselves and their families, or will turn to charities and community organisations to tackle social problems at the local level’ (p. 28).

\section{Compassionate Conservatism was overwhelmed/pushed out by 'events'}

Given the timings, it might be possible to suggest that compassionate Conservatism was pushed off the agenda by the financial crisis of 2008 , the public deficit following the rescuing of the banks, and the consequent perceived need for massive cuts in public expenditure. Perhaps the key question, therefore, is whether the financial crisis provided an excuse for the Conservatives to strengthen their neo-liberal arguments, extending them beyond economic policy into areas of social policy, or whether the crisis was more problematic, in that it drove the Party off its previously desired course. 
There is certainly an argument that Cameron's compassionate approach was already being watered down even before the 2010 general election, whether because of the impact of the financial crisis, and the perceived need for greater reductions in public expenditure, because the compassionate approach was perceived as less necessary, or for other reasons. By the time of the election the compassionate approach had become much less central in Cameron's speeches, with economic policy and the deficit being the Conservatives' central issues. It is arguable that 'following the banking crisis, the narrative changed' (Page 2015b, p. 71), with the Conservatives blaming the Labour government for its addiction to statism, its profligacy with public spending, and its failure to adequately regulate the financial sector, and, as Bale (2013) puts it, the Conservatives' promise to match Labour's public expenditure plans was 'shredded' in favour of massive cuts in public expenditure (see also Dommett, 2015; Gamble, 2015; Williams, 2015).

In 2010, the Programme for Government made clear the primacy of deficit reduction, not only in aiming to reduce it through cuts in public spending, rather than increase taxes, but highlighting in the statement at the end of the document, that, 'The deficit reduction programme takes precedence over any other measures in this agreement...' (p. 35). This emphasised the dominance of the neo-liberal economic approach over most elements of compassionate Conservatism (perhaps with limited exceptions, such as aspects of greater social tolerance) (Vail, 2014), suggested that the government's ambitions for compassion were perhaps limited, and made it all the more unlikely that some of the things that the Conservatives had previously emphasised, such as ending child poverty, would figure significantly in the 
policies of the Coalition government. Indeed, as Kerr and Hayton (2015) note, given the Conservatives' desire to radically reduce the size of the state through austerity measures, it was perhaps immediately questionable whether the newly formed narrative of a more socially liberal and compassionate party was sustainable. Nevertheless, some within the Conservative Party, including Iain Duncan Smith and George Osborne, continued to use the language of compassion, fairness and social justice, although in practice policy, and social security policy in particular, whether as a result of financial pressures or not, headed in a more neo-liberal direction. Indeed, many commentators have suggested that in most, although perhaps not all, areas of social policy, the Liberal Democrats did not act as a significant brake on the neoliberal aspirations of their Conservative partners (for example Beech and Lee, 2015; Seldon and Finn, 2015; Bochel and Powell, 2016).

Electoral and internal pressures, perhaps particularly in relation to the Conservatives' core vote, the challenge of UKIP in the run-up to the 2015 general election, and to some extent the manoeuvring of senior figures for a future leadership election, also had an impact. For example, in addition to the financial crisis, the decline in public support for working-age claimants (Park et al, 2012, 2014; Deeming, 2014) may have helped encourage the Conservatives to move away from parts of the more compassionate narrative they had developed since 2005 . The rise of UKIP, providing a political alternative to the right, meant that there was pressure on the Conservatives to take a fairly hard line in terms of rejecting tax increases and limiting social security payments (other than to pensioners). Similarly, immigration remained an issue upon which the Conservatives continued to take a hard line, at 
least rhetorically, if rather powerlessly, as a result of the demands of EU membership. In addition, Labour's slight shift to the left under Miliband may have made it easier for the Conservatives too to move somewhat away from the centre ground.

Yet, despite this, and in addition to some a reas of social liberalism where, as already discussed, Cameron did largely maintain his pre-election position, there were other areas of social policy where the Conservative Party, as part of the Coalition government, did arguably take a somewhat different line from some of its predecessors, including the commitment to protecting NHS spending, although this, perhaps like the relatively benevolent treatment of pensioners (see also 6, below), may have reflected the Conservatives' perceptions of electoral realities as much as a commitment to a compassionate approach.

5. The ideas underpinning compassionate Conservatism reflected particular, and sometimes different, understandings of 'compassion'

To some extent reflecting many of the arguments made above, it is worth noting that 'compassion' means different things to different people. One obvious example, is that for some compassionate Conservatives poverty may be seen as a bad thing, but also as requiring politicians to be tough to help people escape it; indeed, being compassionate may involve reducing or removing dependency, even if that is not what the individuals themselves might wish for, including, perhaps, drawing on a particular conception of individual morality (Crines, 2013). In a speech in Ottawa, Ian 
Duncan Smith (2015) gave perhaps his clearest explanation of what compassionate Conservatism meant for him. He argued that during the Thatcher and Major premierships, and after, the Conservatives had allowed themselves to be defined by a narrow number of policies, and had failed to apply their values to contemporary challenges. In setting up the Centre for Social Justice, he suggested that his purpose 'was to show that Conservatives cared about people trapped in dependency... spurred on by strong moral values of fairness, opportunity, and compassion'. Moreover, he argued that compassion is not about being 'soft', and while some might feel that it is the preserve of the left:

'I disagree. There is nothing compassionate about increasing dependency by spending more of taxpayers' money to sustain someone in a lifetime on benefits. No, Conservative compassion is about getting someone back to work, taking the tough choices to move someone clear of the benefits system'.

He also criticised the 'sympathetic' approach of the left, which he described as being 'to sustain the most disadvantaged on slightly better incomes'. Here, being 'compassionate' is not the same as being 'sympathetic', and can involve being quite hard on people, albeit in what is perceived as in their own interests. The Conservatives' use of rhetoric on welfare reform has been discussed by Hayton and McEnhill (2014), who note the continuity between New Labour and the Coalition around modernisation and incentivising work, but also the Coalition's, and particularly the Conservatives' use of arguments intended to induce fear (for 
example, over failure to tackle the deficit), promote the view of a strong government, determined to act, and to highlight the dangers of welfare dependency.

While some, such as Toynbee (2013), have argued that Duncan Smith had a second epiphany, and moved from compassion to brutality with his reform of benefits and the Work Programme, others, such as Bamfield (2012: 832) have described the Coalition government's view of social justice as underpinned by the view that:

'far from seeking to maximise the position of those at the bottom, the moral imperative is to reduce state hand-outs to the poorest in society, lest they become trapped in a state of welfare dependency that erodes personal and social responsibility and destroys individual agency and moral autonomy'.

On broadly similar lines, Page has suggested that for the Coalition government, 'progressive' policies were 'based on an equitable or proportionate, as opposed to egalitarian, form of social justice' (2014, p. 24), and that this led to cuts in the living standards of many working age benefit recipients, and to attempts to introduce a 'simpler' and 'fairer' benefit, Universal Credit, intended to ease the transition from benefits to paid work by giving a clear financial advantage to labour market participation. Williams (2015), too, points out that the New Right tradition in conservatism has emphasised equality of opportunity, individual freedom and associated 'meritocratic' principles, with ideas about social justice emphasising rewards for individual success, rather than egalitarian principles.

Indeed, a number of Conservatives, such as Duncan Smith and Willetts, argued that rather than Labour's 'one-dimensional' approach of relying on the benefits system to 
combat poverty, more varied and wide-ranging measures were required to reduce the level of dependency upon the state (Page, 2011). For them tackling Britain's 'broken' society required drawing upon the whole community, rather than relying solely or mainly on the state. They also placed even greater emphasis than had New Labour on individual responsibility. As a result, and despite the greater use of socially inclusive language and the commitment of some Conservatives to equality for samesex couples, it is perhaps unsurprising that Hayton and McEnhill (2015) concluded that 'the socially liberal character of the Conservatives under Cameron's leadership is far from certain' (p. 144).

6. Compassionate Conservatism was present during the Coalition government, but was not much talked about

A somewhat different interpretation from those above moves away from the question of why compassionate Conservatism was not significant under the Coalition government. Instead, it suggests that it may have existed, but that, perhaps with the exception of same-sex marriage, it was not much talked about, as some might suggest that the New Labour governments were in some respects redistributive, but that they did not like to highlight it (Lister, 2001).

Writing in The Daily Telegraph in December 2014, Peter Oborne suggested that 'this Coalition has never banged the drum for its social revolution', but that: 
'Cameron and Clegg have reshaped the relationship between individual and the state in a way which neither Margaret Thatcher nor Tony Blair ever dared to do... [and] Mr Duncan Smith has liberated hundreds of thousands of people from the humiliation of state dependency and given them the opportunity to live independent, responsible and fulfilling lives' (Oborne, 2014).

He argued that in the fields of school age education, welfare reform and employment, in particular, there had been major changes, but that the Coalition had been given little credit, not least because of what he described as Westminster's obsession with the arcane details of everyday politics. Similarly, Michael Gove (2015) argued shortly before the 2015 general election that the Conservatives 'are warriors for the dispossessed', that inequality 'remains the greatest social and political challenge of our time', and continued to lay claim to the Conservatives being the progressive party, with David Cameron having governed 'as a modern, compassionate Conservative'.

It is certainly possible to identify a number of areas where compassionate Conservatives might claim some success. In addition to some of the social liberal ideas discussed throughout this article, the manifesto commitment to increase the UK's international aid to the UN target of 0.7 per cent of GDP made by Michael Howard in 2005 was retained, and in education there was, of course, the introduction of the 'Pupil Premium', designed to give schools additional funding for 'deprived pupils'. However, the Liberal Democrats' manifesto had also contained a commitment to a pupil premi um. Early research on the impact of the Pupil Premium suggested that it had been of value when earmarked for spending on disadvantaged 
pupils (Carpenter et al, 2013), although, in reality, the money was not ring-fenced at school level. In higher education, the introduction of $£ 9000$ tuition fees in England did not appear to have deterred pupils from poorer backgrounds. The protection of NHS funding might also be seen in some respects as compassionate, and as reflecting Cameron's apparent commitment to the NHS prior to the 2010 general election, although the government's reorganisation of the Health Service appeared to have little to do with compassion and more to do with marketisation.

The protection of some areas of spending, meant, or course, larger cuts in others, and in particular working-age benefits, although there was some media discussion of a degree of opposition from the Secretary of State for Work and Pensions, lain Duncan Smith (BBC, 2012b) (there were also suggestions that he supported further changes (for example, Mulholland, 2012)), and from the Liberal Democrats (for example, Syal, 2012). In many respects a major 'cut' resulted from the move from using the Retail Price Index to the Consumer Price Index for the uprating of benefits, tax credits and public service pensions, as CPI tends to be lower than RPI, followed by a cap on the uprating of working age benefits of one per cent per tax year.

Perhaps the greatest changes were in relation to poverty and social security. In Opposition, Cameron had sought to distance the Conservatives from the rhetoric of the Thatcher period, and had, for example, accepted that poverty should be recognised in relative terms, and argued that the pursuit of social justice and social mobility were legitimate goals for the Conservatives. However, the Coalition government was clearly pessimistic about the role of the state in achieving social 
ends, and that, together with the need/desire for public expenditure cuts, led to what many have seen as regressive rather than progressive impacts.

The introduction of Universal Credit was intended to simply the benefits system, and to reduce benefit dependency, as well as giving financial assistance to low-paid workers. However, the roll-out was much slower than had been anticipated. The Coalition replaced Labour's various welfare-to-work programmes with the Work Programme, seen as a more cost-effective way of providing support to those who were unemployed for more than nine months, using private, public or third sector organisations on a payment-by-results basis. Higher payments were given for those seen as likely to need more extensive support in finding a job, such as those receiving Employment and Support Allowance. Assessment for capability to work became an issue, particularly the handling of some of the work by private contractors, most notably Atos, which withdrew from the activity in 2014. Timmins $(2015,327)$ notes that 'the work capability assessment proved so harsh and inaccurate that huge numbers of those turned down won on appeal and the process was subject to repeated revisions'. But perhaps the most significant changes for current purposes were cuts in benefit levels for working-age claimants, with the introduction of a $£ 500$ per week benefit cap for claimant couples, and other reductions, including the withdrawal of the spare room subsidy and the abolition of the national Council Tax rebate scheme. During this period there was also a significant growth in the number of food banks and people using them (more than one million people in $2014 / 15$ according to the Trussell Trust (2015)). 
In relation to social care, one of the service areas most neglected by governments, the Coalition established the Dilnot Commission (the Commission on Funding of Care and Support), which recommended a cap on the maximum that individuals could be expected to pay for their care of $£ 35,000$, although the figure implemented was £72,000. And, despite the passage of the Care Act 2014, which emphasised prevention and the promotion of well-being, the position had arguably deteriorated further, not least as a result of the constraints on funding, so that 'to get any help at all from local social care services requires a higher and ever-rising level of "assessed need"' (Glennerster, 2015: 314).

The Coalition did sometimes highlight austerity initiatives that hit better-off taxpayers, such as the tapered withdrawal of Child Benefit from families where one person earned more than $£ 50,000$, with no payment where an individual earns more than $£ 60,000$, but it is hard to argue that this led to a 'fair' sharing of the burden. In contrast, pensioners were protected from many of the negative impacts of austerity, with increases in the state pension and the retention of other benefits, such as the Winter Fuel Allowance, for older people. One of the other strands of Coalition policy in relation to what they saw as helping people on lower incomes, the raising of the personal allowance, came largely at the insistence of the Liberal Democrats, and, whether seen as compassionate or not, can therefore not be seen as arising directly from compassionate Conservative beliefs.

7. Compassionate Conservatism was complicated and might be reflected in several of these interpretations 
As Page (2011: 39) has noted, 'Conservative "support" for the welfare state has waxed and waned since the Second World War', and has often been linked to calculations over whether it has been operating in ways that bolstered or threatened deeply held Conservative beliefs, such as freedom, responsibility, inequality, voluntarism and the family. Indeed, Cameron's stance on social issues also served to suggest that while he supported the neo-liberal economic agenda of the previous Conservative governments, he realised that the Party had ignored the adverse social consequences of such change (Page, 2011). Beech (2015) has argued that Cameron's position was one of liberal Conservatism, and indeed that the Coalition government was more liberal than conservative, although in reaching that position he also draws upon economic and foreign policy, and it is less clear that such a view might apply when the focus is primarily on social policy. It is also likely that, in the same way as New Labour was significantly influenced by Thatcherism and the 18 years of Conservative government prior to 1997 , as well as by traditional social democratic thinking, in the run-up to the 2010 general election the Conservatives were affected by a variety of political and ideological influences, and that as a result there was something of a mix of ideas and policies within the Party at that time.

Most, if not all, of the possible explanations for the rise and fall of compassionate Conservatism that have been considered above are potentially overlapping. And given the different aims of the 'compassionate' Conservatives, and the variety of influences upon them, it would be surprising if there were one simple interpretation for its fate. Instead, it is perhaps helpful to understand civic, compassionate, modern 
and progressive forms of Conservatism both as rhetorical constructs that were intended to help the Conservatives back into government, and as real drivers for policy change. Even quite early on in his leadership, Finlayson (2007: 4-5) argued that Cameron's strategy could be put down to cynical pragmatism, but noted that he 'combines his acceptance of contemporary standards in personal morality, and his embrace of do-gooder liberalism, with familiar Conservative commitments' in what might be 'an attempt to begun to shape the core of Conservative party ideology around a principle of social responsibility'.

At the same time, however, there were, and continue to be, significant differences among those who have advocated such approaches, and also between them and much of the rest of the Conservative Party, much of which retains a strong attachment to the ideology and rhetoric of the Thatcher period.

\section{Conclusions}

Having tried under three successive leaders to maintain the Thatcherite faith, but with little electoral progress, it may, perhaps, have been almost inevitable that there would be at least a rhetorical change in direction for the Conservative Party. It is interesting to reflect on a speech from the Conservative Party leadership contest in November 2005, which argued:

...Labour's failures have hurt some people most of all. They are the people least able to absorb those failures. I think of the poorest, oldest and most vulnerable members of society... I want to build a Conservative Party that will rescue disadvantaged people from crimeridden estates and failing schools... Many people will be sceptical about 
the Conservative Party presenting itself as a party that cares for society's neediest members. I understand that... The conventional welfare state is letting these people down... We should turn to the voluntary sector, which has a far greater ability to take a holistic approach... Let me be direct with you. The rediscovery of social justice is what will take this party from opposition to government. Of that I have no doubt.

The speaker was David Davis (2005). This suggests that at least some of the arguments about compassionate Conservatism would have been the same even without David Cameron as leader. In terms of David Cameron and the Coalition government, the arguments considered above suggest that each of the first six perspectives outlined in this article helps understand the reasons for the reemergence of compassionate Conservative ideas in the early 2000s. However, that in itself makes clear that the seventh, that compassionate Conservatism during that period was complicated and multi-facted, is the most useful. Indeed, the differences in and between the individuals and groups promoting such ideas, and their motivations for doing so, also help explain why, following the financial crisis and the creation of the Coalition government, 'compassionate' ideas were reflected only to a very limited extent in policy.

Finally, while the focus here has been on compassionate Conservatism and social policy under the Coalition government, the Conservatives' manifesto for the 2015 general election, with the highlighting of the positive impact of 'difficult decisions' (p. 5), including public spending cuts (Conservative Party, 2015), the subsequent Queen's Speech, and the 2015 and 2016 budgets all suggested that without the 'shackles' of coalition, the Party's overall approach remained broadly similar, with 
further implementation of deep and ongoing cuts in public expenditure, increasing marketization and an emphasis on both choice and individual responsibility. While the motives behind the resignation, in March 2016, of Duncan Smith as Secretary of State for Work and Pensions, were questioned, his move raised additional questions about the extent and nature of compassionate Conservatism, including his querying in his letter of resignation whether enough had been done to ensure 'we are all in this together' (BBC, 2016), and whether austerity had largely overwhelmed the desire to create incentives to work in welfare reforms. In addition, the implications of the referendum decision in 2016 to leave the European Union, and the emergence of Theresa May as Prime Minister following David Cameron's resignation, mean that despite the Conservatives' attempts to emphasise ideas such as 'fairness' and to reclaim the 'One Nation' label (Seldon and Snowdon 2015; Bochel and Powell, 2016), the future of modern 'compassionate Conservatism' remains uncertain, at best. 


\section{References}

Bale, T. (2011) The Conservative Party: From Thatcher to Cameron. Cambridge: Polity.

Bale, T. (2012) Wither the Tory left? The demise of progressive conservatism', Juncture 19(2) 84-91.

Bale, T. (2013) What the modernisers did next: From opposition to government - and beyond. Juncture 20(2): 135-43.

Bale, T. and Webb, P. (2013) Members Only: Views of the Conservative Party's Rank and File. Political Insight 4(3): 4-8.

Bamfield, L. (2012) Child Poverty and Social Mobility: Taking the Measure of the Coalition's 'New Approach'. The Political Quarterly 83(4): 830-7.

Baumberg, B. (2014) Benefits and the Cost of Living: Pressures on the Cost of Living and Attitudes to Benefit Claiming. In: A. Park, C. Bryson and J. Curtice (eds.) British Social Attitudes 31. London: NatCen Social Research, pp. 95-120.

BBC (2012a) MP Dorries calls PM and chancellor 'arrogant posh boys'. 23 April, http://www.bbc.co.uk/news/uk-politics-17815769, accessed 26 May 2015.

BBC (2012b) lain Duncan Smith opposes suggested f10bn welfare cuts, 28 April, http://www.bbc.co.uk/news/uk-politics-17877732, accessed 27 May 2015.

BBC (2016) In full: Iain Duncan Smith resignation letter. 18 March, http://www.bbc.co.uk/news/uk-politics-35848891, accessed 30 March 2016. Beech, M. (2011) A Tale of Two Liberalisms. In: M. Beech and S. Lee (eds.) The CameronClegg Government: Coalition Politics in an Age of Austerity. Basingstoke: Palgrave Macmillan, pp. 267-79.

Beech, M. (2015) The Ideology of the Coalition: More Liberal than Conservative. In: M. Beech and S. Lee (eds.) The Conservative-Liberal Coalition: Examining the Cameron-Clegg Government. Basingstoke: Palgrave Macmillan, pp. 1-15. 
Beech, M. and Lee, S. (eds.) (2015) The Conservative-LiberalCoalition: Examining the Cameron-Clegg Government. Basingstoke: Palgrave Macmillan.

Béland, D. and Wadden, A. (2007) Conservative Ideas and Social Policy in the United States. Social Policy and Administration 41(7): 768-786.

Blond, P. (2010) Red Tory: How the Left and Right Have Broken Britain and How We Can Fix It. London: Faber and Faber.

Bochel, H. (1992) Parliament and Welfare Policy. Aldershot: Dartmouth.

Bochel, H. (2011) Conservative approaches to social policy since 1997. In: H. Bochel (ed.) The Conservative Party and Social Policy. Bristol: Policy Press, pp. 1-22.

Bochel, H. and Defty, A. (2007) Welfare Policy under New Labour. Bristol: Policy Press. Bochel, H. and Defty, A. (2010) Power without Representation? The House of Lords and Social Policy. Social Policy and Society 9(3): 367-77.

Bochel, H. and Defty, A. (2014) Parliament and Welfare Policy: The 2010 Intake in the House of Commons, http://policystudiesreseachcentre.blogs.lincoln.ac.uk/files/2015/01/2010Intake-Summary-150115.pdf.

Bochel, H. and Powell, M. (eds.) (2016) The coalition government and social policy. Bristol: Policy Press.

Buckler, S. and Dolowitz, D. (2012) Ideology Matters: Party Competition, Ideological Positioning and the Case of the Conservative Party under David Cameron. British Journal of Politics and International Relations 14(4): 576-94.

Butler, D. and Kavanagh, D. (2005) The British General Election of 2001. Basingstoke: Palgrave.

Cameron, D. (2005) Speech following election as Conservative Party leader, 6December. Cameron, D. (2006a) Improving our NHS. Speech at the King's Fund. London, 4 January. Cameron, D. (2006b) Speech to the Centre for Social Justice. London, 10 July. 
Cameron, D. (2006c) Tackling Poverty is a Social Responsibility. Scarman Lecture. London, 24 November.

Cameron, D. (2009) The Big Society. Hugo Young Lecture. London, 10 November.

Carpenter, H., Papps, I., Bragg, J., Dyson, A., Harris, D., Kerr, K., Todd, L. and Laing, K. (2013)

Evaluation of pupil premium. London, Department for Education.

Clark, G. and Hunt, J. (2007) Who's Progressive Now? London: Conservative Party.

Conservative Party (2010) Invitation to Join the Government of Britain: The Conservative

Manifesto 2010. London: Conservative Party.

Conservative Party (2015) Strong Leadership, A Clear Economic Plan, A Brighter, More Secure

Future. London: Conservative Party.

Crines, A. (2013) The Rhetoric of the Coalition: Governing in the National Interest?

Representation 49(2): 207-218.

Davis, D. (2005) We must champion the victims of Labour failure. Speech. Maidstone, 7 November.

Deeming, C. (2014) Foundations of the Workfare State - Reflections on the Political Transformation of the Welfare State in Britain. Social Policy and Administration, advance online publication 24 September, doi: 10.1111/spol.12096/full.

Defty, A. (2016) The coalition, public opinion and social policy. In: H. Bochel and M. Powell (eds.) The coalition government and social policy. Bristol: Policy Press.

Dommett, K. (2015) The theory and practice of party modernisation: The conservative party under David Cameron, 2005-2015. British Politics 10(2): 249-266.

Duncan Smith, I. (2015) Speech to the Manning Networking Conference. Ottawa, 5 March. Eaton, G. (2014) Duncan Smith can't hide the death of 'compassionate conservatism'. New Statesman, 23 January.

Finlayson, A. (2007) Making Sense of David Cameron. Public Policy Research. 14(1): 3-10.

Gamble, A. (2015) Austerity as Statecraft. Parliamentary Affairs 68(1): 42-57. 
Garnett, M. (2010) Built on Sand? Ideology and Conservative Modernization under David Cameron. In: S. Griffiths and K. Hickson (eds.) British Party Politics and Ideology After New Labour. Basingstoke: Palgrave Macmillan, pp. 107-18.

Glennerster, H. (2015) Health and Long-Term Care. In: A. Seldon and M. Finn (eds.) The Coalition Effect 2010-2015. Cambridge: Cambridge University Press, pp. 290-316.

Gove, M. (2005) Speech to the Good Right Project. London, 12 March.

Griffiths, S. (2012) Cameron's 'Progressive Conservatism' is largely cosmetic and without substance. LSE British Politics and Policy Blog, 19 July, available at:

http://blogs.Ise.ac.uk/politicsandpolicy/camerons-progressive-conservatism-griffiths/, accessed 26 May 2015.

Griffiths, S. (2014) What was Progressive in 'Progressive Conservatism'? PoliticalStudies Review 12(1): 29-40.

Hayton, T. (2014) Conservative Party Statecraft and the Politics of Coalition. Parliamentary Affairs 67(1): 6-24.

Hayton, T. (2015) Fixing Broken Britain. In:T. Heppell and D. Seawright (eds.) Cameron and the Conservatives: The Transition to Coalition Government. Basingstoke: Palgrave Macmillan, pp. 136-148.

Hayton, R. and McEnhill, L. (2014) Rhetoric and Morality - How the Coalition Justifies Welfare Policy. In: J. Atkins, A. Finlayson, J. Martin and N. Turnbull (eds.) Rhetoric in British Politics and Society. Basingstoke: Palgrave Macmillan, pp. 101-115.

Hayton, R. and McEnhill, L. (2015) Cameron's Conservative Party, social liberal ism and social justice. British Politics 10(2): 131-147.

Heppell, T. (2013) Cameron and Liberal Conservatism: Attitudes with in the Parliamentary Conservative Party and Conservative Ministers. British Journal of Politics and International Relations, 15(3): 340-361. 
Heppell, T. and Seawright, D. (eds.) (2015) Cameron and the Conservatives: The Transition to Coalition Government. Basingstoke: Palgrave Macmillan.

Hickson, K. (2008) Conservatism and the Poor: Conservative Party Attitudes to Poverty and Inequality since the 1970s. British Politics 4(3): 342-62.

Hodkinson, S. and Robbins, G. (2012) The return of class war conservatism? Housing under the UK Coalition Government. Critical Social Policy 33(1): 57-77.

Kavanagh, D. and Butler, D. (2005) The British General Election of 2005. Basingstoke:

Palgrave Macmillan.

Kerr, P. and Hayton, R. (2015) Whatever happened to Conservative modernisation? British Politics 10(2): 114-130.

Kirkup, J. (2012) Working Class Resent Cabinet of Rich Men, David Davis Tells Cameron. The Daily Telegraph, 30 March.

Kruger, D. (2007) One Fraternity: Politics Beyond Liberty and Equality. London: Civitas.

Letwin, O. (2002) For Labour There is No Such Thing as Society, Only the State. In: G. Streeter (ed.) There is Such a Thing as Society. London: Politico's, pp. 38-51.

Letwin, O. (2003) Oliver Letwin MP interviewed by Alan Finlayson. From economic revolution to social revolution. In: J. Cruddas and J. Rutherford (eds.) Is the future Conservative?. London: Lawrence and Wishart, pp. 71-8.

Lister, R. (2001) New Labour: a study in ambiguity from a position of ambivalence. Critical Social Policy 21(4): 425-447.

McAnulla, S. (2010) Heirs to Blair's third way? David Cameron's triangulating conservatism. British Politics 5(3): 286-314.

McGrath, J. (2009) Great Expectations: The Conservatives' General Election Campaign. in G. Dallus and I. Dale (eds.) Total Politics Guide to the 2010 General Election in Association with ComRes. London: Biteback, pp. 34-8.

May, T. (2002) Speech to the Conservative Party Conference. Bournemouth, 7October. 
Maude, F. (2005) 21st Century Conservatism. Speech to the Centre for Policy Studies.

London, 15 June.

Mulholland, H. (2012) lain Duncan Smith targets families of more than two children for benefit cuts. The Guardian, 25 October.

Norman, J. and Ganesh, J. (2006) Compassionate Conservatism: What it is, Why we need it. London: Policy Exchange.

Norman, J. (2009) Compassionate Economics: The social foundations of economic prosperity. London: Policy Exchange.

Oborne, P. (2014) This Coalition has never banged the drum for its social revolution. The Daily Telegraph, 24 December.

Olafsky, M. (2000) Compassionate Conservatism: What it is, What it Does, and How it Can Transform America. New York: Free Press.

Osborne, G. (2009) Progressive reform in an age of austerity. Speech to Demos. London, 11 August.

Page, R. (2010) David Cameron's Modern Conservative approach to poverty and social justice: towards one nation or two? Journal of Poverty and Social Justice 18(2) 147-60. Page, R. (2011) The Conservative Party and the welfare state since 1945. In: H. Bochel (ed.) The Conservative Party and Social Policy. Bristol: Policy Press, pp. 23-39.

Page, R. (2014) 'Progressive' Turns in Post-1945 Conservative Social Policy. Political Studies Review. 12(1): 17-28.

Page, R. (2015a) Clear blue water? The Conservative Party and the welfare state since 1940. Bristol: Policy Press.

Page, R. (2015b) The Coalition, Poverty and Social Security. In M. Beech and S. Lee (eds.) The Conservative-Liberal Coalition: Examining the Cameron-Clegg Government. Basingstoke: Palgrave Macmillan, pp. 68-85. 
Park, A., Clery, E., Curtice, J., Phillips, M. and Utting, D. (eds.) (2012) British Social Attitudes 28. London: Sage.

Park, A., Bryson, C., Clery, E., Curtice, J. and Phillips, M. (eds.) (2014) British SocialAttitudes 30. London: Sage.

Patrick, R. (2015) Rhetoric and reality: exploring lived experiences of welfare reform under the Coalition. In: L. Foster, A. Brunton, C. Deeming and T. Haux (eds.) In Defence of Welfare 2. Bristol: Social Policy Association, pp. 24-27.

Pautz, H. (2013) The Think Tanks behind Cameronism. British Journal of Politics and International Relations 15(3): 362-77.

Rawnsley, A. (2009) David Cameron Needs More Than a Clique of Four to Succeed. The Observer, 15 March: p. 31.

Robinson, E. and Twyman, J. (2014) Speaking at Cross Purposes? The Rhetorical Problems of ‘Progressive’ Politics. PoliticalStudies Review 12(2): 51-67.

Seldon, A. and Snowdon, P. (2005) The Conservative Party. In: A. Seldon and D. Kavanagh (eds.) The Blair effect 2001-5. Cambridge: Cambridge University Press, pp. 131-56.

Seldon, A. and Finn, M. (eds.) (2015) The Coalition Effect, 2010-2015. Cambridge: Cambridge University Press.

Seldon, A. and Snowdon, P. (2015) Cameron at 10, London: William Collins.

Syal, R. (2012) Nick Clegg risks Lib Dem-Tory coalition by spelling out differences. The Guardian. 17 December.

Taylor-Gooby, P. (2013) The Double Crisis of the Welfare State and What We Can Do About It. Basingstoke: Palgrave Macmillan.

Timmins, N. (2015) Welfare. In: A. Seldon and M. Finn (eds.) The Coalition Effect 2010-2015. Cambridge: Cambridge University Press, pp. 317-44.

Toynbee, P. (2013) lain Duncan Smith's second epiphany: from compassion to brutality. The Guardian, comment is free. 8 November, 
http://www.theguardian.com/commentisfree/2013/nov/08/duncan-smith-poverty-benefitsanctions-easterhouse, accessed 10 March 2015.

Trussell Trust (2015) 'Foodbank use tops one million for first time says Trussell Trust', available at: http://www.trusselltrust.org/resources/documents/Press/Trussell-Trustfoodbank-use-tops-one-million.pdf, accessed 28 April 2015.

Vail, M. (2015) Between One-Nation Toryism and Neoliberal ism: The Dilemmas of British Conservatism and Britain's Evolving Place in Europe. Journal of Common Market Studies 53(1): 106-122.

Webb, P. and Childs, S. (2011) Wets and Dries Resurgent? Intra-Party Alignments Among Contemporary Conservative Party Members. Parliamentary Affairs 64(3): 383-402.

Wiggan, J. (2011) Something old and blue, or red, bold and new? In: C. Holden, M. Kilkey and G. Ramia (eds.) Social Policy Review 23. Bristol: Policy Press, pp. 25-43.

Willetts, D. (1992) Modern Conservatism. The Political Quarterly, 63(4): 224-232.

Willetts, D. (1994) Civic Conservatism. London: Social Market Foundation.

Willetts, D. (2002) The New Contours of British Politics. In: G. Streeter (ed.) There is Such a Thing as Society. London: Politico's, pp. 52-9.

Willetts, D. (2005a) Compassionate Conservatism and the war on poverty. Speech to the Centre for Social Justice. London, 6 January.

Willetts, D. (2005b) A new Conservatism for a new century. Speech to the Social Market Foundation. London, 2June.

Williams, B. (2015) The Evolution of Conservative Party Social Policy. Basingstoke: Palgrave Macmillan.

Wright, O. (2012) End of 'compassionate Conservatism' as David Cameron details plans for crackdown on welfare. The Independent, 25 June. 